\title{
ORIGAMI untuk Meningkatkan Efikasi Diri: Mengajarkan Pencegahan KSA pada Orang Tua dengan Anak Tunarungu
}

\section{ORIGAMI in Improving Parental Self-efficacy: Teaching Prevention of Child Sexual Abuse for Children with Hard of Hearing}

\author{
Sitti Wahyuni ${ }^{1}$, Supra Wimbarti ${ }^{2}$ \\ 1,2Fakultas Psikologi, Universitas Gadjah Mada
}

\begin{abstract}
Self-efficacy is one component of the attitude that must be possessed by every parent, especially in teaching prevention of child sexual abuse (CSA). In this study, child with hard of hearing. In reality, parents are often confused when they have to teach CSA to children so they need a training to increase their knowledge and skills in teaching prevention of CSA. ORIGAMI is one of training that can improve parental self-efficacy in teaching prevention of CSA in hard of hearing children. The study was conducted using the untreated control group design method with dependent pretest and posttest samples. Participants in this study were 28 parents who had hard of hearing children aged 10-12 years old, which 14 parents in an experiment group and 14 parents in a control group. The results of statistical analysis using anova mixed design showed that the level of self-efficacy in the experimental group differed significantly from the control group $(F=13.617$ and $p=0.000)$. The result showed that ORIGAMI's training can effectively improve parental self-efficacy to teach prevention of CSA for children in hard of hearing.
\end{abstract}

Keywords: child sexual abuse; hard of hearing; parental self-efficacy

Abstrak. Efikasi diri merupakan salah satu komponen sikap yang harus dimiliki oleh setiap orang tua, khususnya dalam mengajarkan pencegahan kekerasan seksual pada anak. Pada penelitian ini anak secara lebih spesifik merupakan anak yang mengalami hambatan dalam pendengaran (tunarungu). Orang tua seringkali kebingungan ketika harus mengajarkan tentang KSA pada anak sehingga mereka membutuhkan sebuah pelatihan yang dapat melatih mereka untuk meningkatkan pengetahuan serta keterampilan dalam mengajarkan pencegahan KSA pada anak. Pelatihan ORIGAMI merupakan salah satu media yang dapat meningkatkan efikasi diri orang tua dalam mengajarkan pencegahan KSA pada anak tunarungu. Penelitian dilakukan dengan metode untreated control group design with dependent pretest and posttest samples. Partisipan dalam penelitian ini adalah 28 orang tua yang memiliki anak tunarungu berusia 1012 tahun, di mana 14 orang tua tergabung di dalam kelompok eksperimen dan 14 lainnya dalam kelompok kontrol. Hasil analisis statistik menggunakan anova mixed design menunjukkan bahwa tingkat efikasi diri pada kelompok eksperimen berbeda secara signifikan dengan kelompok kontrol $(F=13,617$ dan $p=0,000)$. Hasil penelitian menunjukkan bahwa pelatihan ORIGAMI dapat secara efektif meningkatkan efikasi diri orang tua dalam mengajarkan pencegahan kekerasan seksual pada anak tunarungu.

Kata kunci: efikasi diri orang tua; kekerasan seksual pada anak; tunarungu 
Kekerasan seksual pada anak (yang selanjutnya akan disingkat menjadi KSA) adalah segala aktivitas seksual yang dikenakan pada anak dan dilakukan dalam bentuk paksaan maupun ancaman oleh orang dewasa atau teman sebayanya (Finkelhor, 2009; Richter et al., 2015; Belur \& Singh, 2015). Senada dengan paparan beberapa peneliti lain yang menyebutkan bahwa KSA merupakan aktivitas seksual oleh orang dewasa atau teman sebaya, yang dilakukan untuk memperoleh kepuasan seksual dengan diikuti oleh paksaan, ancaman, rayuan, bahkan penipuan (Kinnear, 2007), terhadap anak di bawah umur (Carson et al., 2013; Finkelhor, 2009; Hornor, 2010; Johnson, 2004), yang secara hukum belum mampu memberikan persetujuan (Finkelhor, 2009; Kellogg, 2005; Modelli et al., 2012), baik anak memahaminya atau tidak (Davies \& Jones, 2013). Anak-anak sangat rentan menjadi korban kekerasan seksual, hal ini dibuktikan dengan tingginya angka kejadian kekerasan seksual pada anak. Meskipun banyak anak dan remaja yang menjadi korban dan gagal dalam mengungkapkan pengalaman seksual mereka, namun angka korban kekerasan seksual terus bertambah (McLean et al., 2014).

Sementara itu, kasus KSA akan lebih rentan dialami oleh anak-anak dengan disabilitas (Skarbek et al., 2009; Sullivan \& Knutson, 2000). Tunarungu merupakan salah satu di antaranya. Terbatasnya kemampuan mereka dalam berkomunikasi, membuat anak-anak dengan kesulitan pendengaran ini menjadi sasaran para mafia seksual. Berdasarkan penelitian yang dilakukan terhadap 3000 anak di Amerika Serikat, menunjukkan bahwa anak-anak dengan kesulitan berbicara dan berbahasa memiliki risiko lima kali lebih besar mengalami kekerasan dan tiga kali lebih besar mengalami kekerasan secara seksual (Sullivan \& Knutson, 2000). Survei lainnya dilakukan di Amerika kepada 770 mahasiswa tunarungu, yang memperlihatkan bahwa sebanyak 45\% dari mereka mengalami beberapa jenis kekerasan selama masa anak-anak, salah satu di antaranya adalah kekerasan secara seksual (Embry, 2001). Anak-anak ini tidak hanya mengalami kekerasan seksual dikarenakan keterbatasan yang dimilikinya, namun terbatasnya pengetahuan masyarakat tentang kebutuhan disabilitas juga menjadi salah satu faktor penyebab (Child Welfare Information Gateaway, 2018). Pada tahun 2014 Komisi Nasional Anti Kekerasan terhadap Perempuan (Komnas Perempuan) melengkapi formulir pendataan mengenai kekerasan yang dialami perempuan dengan disabilitas, di mana di antara kasus tersebut tunarungu yang menjadi korban terbanyak (Komnas Perempuan, 2018).

Orang tua sebagai pendidik pertama bagi anak dituntut untuk selalu waspada terhadap bahaya pelaku KSA, harus mampu menjaga anak tetap aman dengan menjaga komunikasi dalam keluarga, dan mengajarkan anak untuk memahami dan berani menolak pada saat ada orang lain yang menempatkan anak dalam sebuah situasi yang membuatnya tidak nyaman (Walsh \& Brandon, 2012). Orang tua dianggap dapat menjadi agen yang efektif dalam menjalankan program prevensi ini karena orang tua sendiri merupakan kunci keberhasilan dalam tindakan pencegahan KSA (Xie et al., 2015). Kesuksesan program prevensi KSA di sekolah juga sangat dipengaruhi oleh orang tua. Ketika orang tua telah dilatih untuk menjadi prevention educators, anak dapat menerima latihan dan informasi secara berulang-ulang yang dapat mendukung keberhasilan dalam program prevensi dari 
sekolah, termasuk penjelasan dan pengaplikasian ilmu baru pada keseharian mereka (Mardhiyah, 2017; Wurtele et al., 2008; Wurtele \& Kenny, 2010).

Anak yang belajar perlindungan diri dari KSA melalui orang tua terbukti lebih terampil mengatasi permintaan terhadap sentuhan buruk dibandingkan dengan anak yang dilatih oleh guru (Wurtele, 2008). Selain itu, sebagai agen KSA, orang tua dinilai lebih leluasa dan fleksibel terkait dengan waktu dan interaksi yang dilakukannya bersama anak dibandingkan dengan orang lain (Wurtele \& Kenny, 2010). Pada kenyataannya, sedikit sekali orang tua yang memberikan pendidikan seksual kepada anak mereka sejak dini.

Penelitian menyebutkan bahwa banyak orang tua yang tidak pernah berdiskusi masalah seks bersama anak, sekitar 38\%-54\% ibu tidak pernah membahas tentang seks dengan anak (Nyarko et al., 2014). Hal ini disebabkan karena orang tua merasa kekurangan pengetahuan, kosakata, dan materi mengenai KSA, sehingga mereka butuh adanya pelatihan dan pendampingan dari ahli (Wurtele \& Kenny, 2010). Terlebih pada orang tua yang memiliki anak tunarungu. Kesulitan yang mereka rasakan adalah terkait dengan pemahaman anak dan cara penyampaian (Quittner et al., 2011).

Kondisi tersebut pada akhirnya membuat orang tua merasa tidak yakin dalam menyampaikan pengetahuan mengenai pencegahan kekerasan seksual anak (KSA) kepada anak mereka. Keyakinan individu dalam mengelola dan melaksanakan tindakan yang dibutuhkan pada situasi tertentu disebut dengan self-efficacy atau efikasi diri (Bandura, 1997). Sementara, pada penelitian ini efikasi diri tersebut terkait dengan peran orang tua dalam mengajarkan pencegahan KSA pada anak tunarungu.

Modul ORIGAMI merupakan akronim dari "Orang tua Mengajari, Menjaga, dan Melindungi Diri". Modul ini adalah sebuah media yang di rancang oleh Narcosetyo (2017) sebagai salah satu langkah intervensi dengan metode pelatihan. Materi yang termuat dalam modul tersebut berupa materi tentang KSA dan langkah-langkah yang dapat diajarkan kepada orang tua untuk menghindari anak mereka terhadap bahaya KSA, sehingga dapat disimpulkan bahwa sebesar $25 \%$ berisi teori dan $75 \%$ dari modul ini berisi praktik atau latihan. Modul juga dilengkapi dengan flipchart berupa gambar-gambar yang mempermudah anak-anak tunarungu untuk memahami apa yang disampaikan oleh orang tuanya.

Pada penelitian ini, peneliti akan menggunakan modul ORIGAMI dengan beberapa modifikasi yang disesuaikan dengan karakteristik partisipan dan kondisi di lapangan. Berdasarkan penelitian sebelumnya, ORIGAMI mampu untuk meningkatkan pengetahuan dan keterampilan orang tua dalam menyampaikan KSA. Oleh karena itu, tujuan penggunaan modul dalam penelitian ini adalah untuk meningkatkan keyakinan orang tua dalam mengajarkan pencegahan KSA kepada anak mereka, setelah pengetahuan dan keterampilan mereka meningkat.

Tujuan dari penelitian ini adalah untuk menguji apakah program "ORIGAMI" mampu untuk meningkatkan efikasi pada orang tua yang memiliki anak tunarungu dalam mengajarkan pencegahan KSA. Penelitian ini diharapkan dapat memberikan kontribusi dalam pengembangan keilmuan, khususnya di bidang psikologi pendidikan, terkait efikasi 
pada orang tua yang memiliki anak tunarungu sebagai prevensi kekerasan seksual. Manfaat praktis dari penelitian ini adalah program "ORIGAMI" ini nantinya dapat diterapkan pada orang tua yang memiliki anak tunarungu sebagai media dalam dalam mengajarkan pencegahan KSA.

\section{Metode}

\section{Desain penelitian}

Penelitian ini menggunakan pendekatan kuantitatif dengan metode quasi experiment, di mana desain rancangannya adalah untreated control group design with dependent pretest and post-test samples (Shadish et al., 2002). Penelitian ini menggunakan dua kelompok, yaitu kelompok eksperimen dan kelompok kontrol. Kelompok eksperimen mendapatkan perlakuan berupa intervensi dalam bentuk psikoedukasi pelatihan melalui program “ORIGAMI" (Orang tua Mengajari, Menjaga, dan Melindungi Diri), yang terdiri dari empat sesi pelatihan. Sedangkan kelompok kontrol tidak diberikan tritmen atau perlakuan. Gambar 1 menunjukkan desain penelitian.

\section{Partisipan penelitian}

Partisipan yang dilibatkan dalam penelitian ini adalah 28 orang tua (yang dapat diwakili oleh ayah saja atau ibu saja) yang memiliki anak tunarungu yang bersekolah di SLB-B $X$ yang dibagi ke dalam dua kelompok. Kelompok eksperimen sebanyak 14 orang dan 14 orang lainnya termasuk ke dalam kelompok kontrol. Adapun kriteria partisipan dalam penelitian ini adalah orang tua yang memiliki anak tunarungu usia 10-12 tahun, di mana pada usia ini anak mulai tertarik dengan berbagai fungsi tubuhnya yang telah mengalami perubahan dan mulai mengalami masa pubertas. Orang tua dengan latar belakang pendidikan minimal SMA,tinggal satu rumah bersama anak (tunarungu), orang tua yang belum pernah mendapatkan program prevensi KSA sebelumnya dan tidak sedang dalam proses intervensi psikologis lainnya pada saat mengikuti pelatihan, serta orang tua yang menyetujui informed consent dan bersedia menandatanganinya.

\section{Analisis data}

Analisis data yang digunakan dalam penelitian ini adalah anova mixed design, yang akan memadukan dua sub analisis. Kedua sub analisis tersebut adalah within subject test dan between subject test.

\section{Hasil}

\section{Efikasi Diri Orang tua dalam Mengajarkan Pencegahan KSA}

Hasil analisis menunjukkan bahwa nilai $F=13,617$ dan nilai signifikansi 0,000 $(p<0,01)$. Artinya bahwa terdapat interaksi antara time (pretest dan posttest) dan group (kelompok eksperimen dan kelompok kontrol). Interaksi menunjukkan bahwa perubahan skor efikasi 
diri sebelum dan sesudah pelatihan pada kedua kelompok adalah berbeda secara signifikan (Widhiarso, 2011). Perubahan skor yang terjadi antara dua kelompok dapat dilihat pada Tabel 1.

Tabel 1.

Perubahan Skor Efikasi Diri Antar Kelompok

\begin{tabular}{cccc}
\hline Kelompok & Selisih Rerata & Nilai Signifikansi & Partial Eta Squared \\
\hline Eksperimen & $-20,786$ & $0,000(\mathrm{p}<0,01)$ & 0,587 \\
Kontrol & $-1,464$ & $0,675(\mathrm{p}>0,05)$ & 0,031 \\
\hline
\end{tabular}

Berdasarkan Tabel 1, dapat diketahui bahwa terdapat perubahan yang signifikan antara skor efikasi diri sebelum dan setelah pelatihan pada kelompok eksperimen, namun tidak terdapat perubahan yang signifikan antara skor efikasi diri sebelum dan setelah pelatihan pada kelompok kontrol. Oleh karena itu, dapat disimpulkan bahwa pelatihan ORIGAMI yang diberikan pada kelompok eksperimen cukup efektif dalam meningkatkan efikasi diri partisipan. Pelatihan ORIGAMI memberikan kontribusi efektif sebesar 58,7\% terhadap peningkatan efikasi diri.

\section{Pengetahuan KSA}

Hasil analisis yang diperoleh menunjukkan bahwa perubahan skor tes pengetahuan antara kedua kelompok (eksperimen dan kontrol) dan juga waktu (pretest, postest, dan follow-up) tidak signifikan, dengan nilai $F=1,366$ dan $p=0,264(p>0,05)$. Artinya, tidak ada perbedaan skor tes pengetahuan tentang KSA antara kedua kelompok (eksperimen dan kontrol) dan waktu (pretest, postest, dan follow-up) (Widhiarso, 2011). Seperti yang terlihat pada Tabel 2 berikut.

Tabel 2.

Perubahan Skor Tes Pengetahuan Antar Kelompok

\begin{tabular}{cccc} 
Waktu & Kelompok & Selisih Rerata & SD \\
\multirow{2}{*}{ Pretest } & Eksperimen & 17,28 & 3,75 \\
& Kontrol & 17,64 & 2,30 \\
\hline \multirow{2}{*}{ Postest } & Eksperimen & 18,28 & 3,75 \\
& Kontrol & 17,78 & 2,51 \\
\hline \multirow{2}{*}{ Follow-up } & Eksperimen & 19 & 2,15 \\
& Kontrol & 17,85 & 2,60 \\
\hline
\end{tabular}

\section{Diskusi}

Berdasarkan hasil penelitian, terjadi perubahan yang signifikan antara skor efikasi diri sebelum dan setelah pelatihan pada kelompok eksperimen, namun tidak terjadi perubahan 
yang signifikan antara skor efikasi diri sebelum dan setelah pelatihan pada kelompok kontrol. Oleh karena itu, dapat disimpulkan bahwa pelatihan ORIGAMI yang diberikan pada kelompok eksperimen efektif dalam meningkatkan efikasi diri orang tua yang memiliki anak tunarungu dalam mengajarkan pencegahan KSA, dengan sumbangan efektif sebesar 58,7\%. Pemaparan tersebut menunjukkan bahwa hipotesis diterima. Keseluruhan proses pelatihan juga diukur secara kualitatif. Hasil yang diperoleh mengindikasikan bahwa hampir seluruh partisipan mampu menyerap materi secara menyeluruh. Para partisipan juga dinilai antusias dan terlibat aktif selama proses pelatihan, sehingga skor efikasi diri pada partisipan meningkat setelah mengikuti pelatihan ORIGAMI.

Keberhasilan pelatihan ORIGAMI yang telah dicapai dalam penelitian ini mendukung sejumlah penelitian sebelumnya yang menemukan bahwa efikasi diri dapat ditingkatkan melalui pelatihan (Sanders \& Woolley, 2005). Selanjutnya, kajian literatur yang dilakukan oleh Buck (2014) juga menunjukkan bahwa efikasi sangat efektif ketika dilatihkan bersamaan dengan teknik Behavioral Skill Training (BST), karena di dalamnya sekaligus mengajarkan skill yang dapat menjadi acuan, dalam penelitian ini bagi para orang tua, untuk meningkatkan keterampilan dalam mengajarkan pencegahan KSA pada anak mereka. BST merupakan serangkaian paket pengajaran yang terdiri dari kombinasi metode, yang ketika digunakan bersamaan metode ini akan menciptakan sebuah teknik yang efektif untuk mengajar sesuatu hal yang baru kepada individu (LaBrot et al., 2017).

Melalui pelatihan yang berlangsung juga para orang tua saling berbagi mengenai cara ataupun strategi yang telah dilakukan selama ini dalam mengajarkan bagian-bagian pribadi anak yang merupakan salah satu cara mencegah KSA. Hal ini juga merupakan salah satu cara untuk meningkatkan efikasi diri seseorang, dimana mereka membagikan pengalamannya serta mendengarkan pengalaman orang lain dalam setiap sesi (Bloomfield \& Kendall, 2012). Modul ini juga disertai dengan praktik dalam mengajarkan prevensi KSA, dengan landasan pembelajaran observasional (Bandura, 1986), yang terdiri dari empat tahap.

Pertama, proses atensi yang terdapat dalam kegiatan pada saat melihat cuplikan film dan memperhatikan model praktik selama pelatihan berlangsung. Kedua, proses retensi yaitu proses pada saat para peserta menerima informasi, baik melalui ceramah maupun membaca petunjuk praktik dari flipchart yang telah disediakan. Ketiga, proses produksi yang ditunjukkan dari para peserta ketika mereka diminta untk mengingat kembali materi yang telah diberikan melalui "tes pengingat" dalam setiap sesi. Selain itu, para peserta juga diminta untuk praktek secara mandiri dalam beberapa kelompok kecil setelah sebelumnya dicontohkan oleh model. Keempat adalah motivasi di mana ketika para peserta diminta untuk menuliskan refleksi pengalaman positif, tantangan yang dialami pada setiap sesi, dan niatan ataupun rencana yang akan dilakukan setelah mengikuti pelatihan.

Keberhasilan pelatihan juga disebabkan oleh beberapa faktor yang ditemukan di lapangan. Faktor tersebut terdiri dari beberapa aspek, yaitu faktor orang tua, anak, sekolah, dan trainer. Faktor orang tua disebabkan karena seluruh anaknya berasal dari sekolah yang sama. Hal ini membuat suasana pelatihan menjadi lebih "hidup" karena antar partisipan 
sudah saling mengenal dan membuat kelompok yang homogen. Kondisi ini juga membuat para partisipan lebih merasa "in-group" dan lebih terbuka pada saat diskusi. Sebagaimana penjelasan Gray et al. (2014) dalam penelitiannya yang menyebutkan bahwa homogenitas di dalam sebuah kelompok terbentuk karena adanya hubungan timbal balik dan hubungan berdasarkan pengalaman, sehingga sebuah kelompok akan tetap homogeny meskipun populasinya bertambah (Gray et al., 2014)

Faktor berikutnya adalah karakteristik anak yang sebagian besar mengalami partially deaf, di mana mereka masih memiliki sisa batas pendengaran dan mayoritas mereka juga menggunakan ABD (Alat Bantu Dengar). Kondisi lainnya adalah karena anak-anak yang cepat mendapatkan stimulasi pendidikan yaitu ketika usia lima tahun ke bawah dan mereka juga dimasukkan ke sekolah khusus tunarungu sehingga dari segi komunikasi juga cepat terbantu. Hal ini juga dijelaskan dalam penelitian Luft (2017), bahwa anak-anak dengan kesulitan pendengaran yang mendapatkan pendidikan, khususnya dalam peningkatan bahasa, sejak usia tiga tahun akan lebih siap untuk berinteraksi dengan anak seusia mereka (termasuk yang tidak memiliki permasalahan yang sama) dan memiliki peningkatan prestasi. Tentunya kondisi tersebut harus disertai dengan fasilitas yang memadai (Luft, 2017).

Selanjutnya adalah faktor sekolah yang lebih menekankan penggunaan komunikasi secara oral atau verbal (bukan isyarat). Hal ini memudahkan orang tua untuk dapat berkomunikasi langsung dengan anak, termasuk trainer pada saat menyampaikan materi pelatihan. Meskipun trainer merupakan ahli di bidang KSA, namun ia bukan ahli di bidang tunarungu sehingga kondisi ini tidak membuat permasalahan karena komunikasi yang biasa terjadi antara orang tua dan anak adalah oral atau verbal. Alasan ini pula yang menjadi salah satu kekuatan tingkat kestabilan skor efikasi diri orang tua pada saat pengukuran follow-up.

Sebaliknya, skor tes pengetahuan pada kedua kelompok tidak mengalami perubahan yang signifikan. Artinya, dengan kata lain perubahan skor yang terjadi antar kelompok tidak berbeda. Berdasarkan hasil tersebut maka dapat disimpulkan bahwa peningkatan skor efikasi diri yang terjadi karena pelatihan ORIGAMI tidak berbanding lurus dengan peningkatan skor pengetahuan tentang KSA. Hal ini dipengaruhi oleh beberapa faktor, beberapa di antaranya adalah faktor latar belakang pendidikan para partisipan yang sangat beragam. Rata-rata mereka berpendidikan SMA dan D3 bahkan ada yang S2, sehingga pada saat pretest pun jawaban yang diberikan sudah jauh di atas ekspektasi peneliti, sehingga tidak banyak ditemukan kekeliruan dalam pengisian jawaban.

Pengaruh lainnya adalah di dalam pelatihan ORIGAMI memuat 25 persen materi dan 75 persen praktik, sehingga pada dari segi pengetahuan tidak meningkat secara signifikan dibandingkan dengan keterampilan karena efikasi diri memang lebih mudah ditingkatkan dengan metode praktik. Teknik BST yang diajarkan di dalam modul ORIGAMI sangat membuat partisipan menyerap dengan baik materi yang dipraktikkan langsung dengan cara role play. Hal ini senada dengan penjelasan Bandura (dalam Rustika, 2012) bahwa efikasi diri dapat dibentuk melalui: (1) pengalaman berhasil, dimana seseorang yang pernah memiliki 
pengalaman yang baik dan sukses maka akan meningkatkan efikasi dirinya. Begitu sebaliknya. (2) peristiwa yang seakan dialami sendiri, kondisi ini merepresentasikan sebuah peristiwa yang dapat dimaknai oleh individu sebagai sebuah kondisi yang mencerminkan apa yang terjadi padanya. Kondisi tersebut melibatkan seorang figur atau model. Figur tersebut ada di dalam kehidupan sehari-hari, baik yang dapat teramati secara langsung ataupun yang diamati melalui media visual. Pada konteks inilah pembelajaran observasional berlangsung (Rustika, 2012).

Keterbatasan dalam penelitian ini adalah asumsi awal dari peneliti yang membatasi kriteria partisipan berdasarkan latar belakang pendidikan (minimal SMA), namun karena keterbatasan jumlah partisipan di lapangan mengharuskan peneliti untuk mengambil seluruh populasi tanpa memperhatikan latar belakang pendidikan dan hanya di kontrol oleh usia anak (10-12 tahun). Terdapat dua partisipan yang berpendidikan SD dan SMP, dimana kondisi yang terjadi pada mereka juga cenderung sama dengan partisipan lainnya yaitu mengalami peningkatan skor efikasi diri. Hal ini dapat dikaitkan dengan teori Bandura (1997) yang menjelaskan bahwa faktor-faktor yang dapat memengaruhi efikasi diri adalah budaya, jender, sifat dari tugas yang dihadapi, dukungan eksternal, status individu di lingkungan, dan penilaian tentang kemampuan diri (Bandura, 1997). Tidak disebutkan sama sekali faktor latar belakang pendidikan pada teori tersebut, sehingga pada partisipan dengan latar belakang pendidikan S2 pun tidak lebih tinggi efikasi dirinya daripada partisipan SMA maupun D3.

Keterbatasan lain pada penelitian ini adalah pada validitas internal seperti social desirability, yang dapat memengaruhi variabilitas dari skor skala, validitas, serta reliabilitas dari alat ukur tersebut (Shultz et al., 2014). Nunnaly dan Bernstein (1994) menjelaskan bahwa social desirability bertanggung jawab atas sebagaian besar variasi data yang dikumpulkan dengan kuesioner self-report yang di ukur berdasarkan rentang angka (interval). Penelitian ini menggunakan alat ukur efikasi diri orang tua dalam mengajarkan pencegahan KSA dalam bentuk skala interval. Hal ini dapat menjadi salah satu kelemahan karena selalu ada kemungkinan subjek memberikan jawaban yang diterima oleh masyarakat secara umum.

\section{Kesimpulan}

Berdasarkan hasil penelitian yang telah dilakukan, maka dapat disimpulkan bahwa pelatihan ORIGAMI dapat meningkatkan efikasi diri orang tua yang memiliki anak tunarungu dalam mengajarkan pencegahan KSA. Pelatihan ORIGAMI disusun dari teori belajar observasional dengan menggunakan teknik BST (Behavioral Skill Training). Pembelajaran yang diperoleh partisipan dari pelatihan ORIGAMI diukur dengan checklist perilaku BST, sedangkan perubahan perilaku diukur dengan skala efikasi diri.

Peningkatan efikasi diri yang dialami oleh partisipan disebabkan adanya pelatihan yang diberikan. Hal ini dipertegas pula oleh hasil observasi yang dilakukan tim pengamat, evaluasi, dan juga refleksi yang dituliskan oleh para partisipan. Hampir seluruh partisipan 
menilai pelatihan yang diberikan berdampak positif untuk diri mereka, sehingga antusiasme mereka pun meningkat dan ditunjukkan dengan keterlibatan mereka secara aktif selama pelatihan berlangsung.

\section{Saran}

Partisipan diharapkan tetap mempraktikkan segala cara-cara yang dapat dilakukan dalam pencegahan KSA, yang dapat disertai dengan panduan yang telah dibagikan. Hargailah setiap proses pembelajaran yang dilakukan bersama anak, meskipun prosesnya terjadi secara perlahan. Sekolah juga diharapkan dapat terus mengadakan pelatihan serupa secara rutin dengan mengundang ahli ataupun pemateri yang dapat memberikan program ini dengan baik. Orang tua membutuhkan bekal yang cukup agar mereka siap untuk mengajarkan berbagai pencegahan Kekerasan Seksual pada Anak, khususnya anak-anak tunarungu.

Bagi peneliti selanjutnya diharapkan dapat mengarahkan penelitian pada partisipan yang memiliki anak dengan gangguan ataupun hambatan lainnya agar terlihat variasi dan perbedaan yang ditimbulkan, melibatkan kedua orang tua sebagai partisipan agar keduanya mengetahui dan mendapatkan informasi secara bersamaan, menggunakan variabel psikologi yang lain untuk mengungkap tema KSA. Jika di masa yang akan datang peneliti selanjutnya akan menggunakan modul ini kembali, maka perlu dipertimbangkan untuk adanya penyempurnaan modul dan flipchart yang digunakan. Juga penting untuk mengukur keberhasilan program dengan mengukur perkembangan ataupun ketercapaian anak.

\section{Kepustakaan}

Bandura, A. (1986). Social foundations of thought and action: A social cognitive theory. Upper Saddle River, NJ: Prentice-Hall, Inc.

Bandura, A. (1997). Self efficacy: The exercise of control. New York: W. H. Freeman and Company.

Belur, J., \& Singh, B. B. (2015). Child sexual abuse and the law in India: A commentary. Journal of Crime Science, 4(1), 1-6. https://doi.org/10.1186/s40163-015-0037-2

Bloomfield, L. \& Kendall, S. (2012). Parenting self-efficacy, parenting stress and child behaviour before and after a parenting programme. Primary Health Care Research $\mathcal{E}$ Development, 13(4), 364-372. https://doi.org/10.1017/s1463423612000060

Buck, H. M. (2014). The efficacy of behavioral skills training: A literature review. Southern Illinois University.

Carson, D. K., Foster, J. M., \& Tripathi, N. (2013). Child sexual abuse in India: Current issues and research. Journal of Psychological Studies, 58(3), 318-325. https://doi.org/10.1007/s12646-013-0198-6

Komisi Nasional Anti Kekerasan terhadap Perempuan [Komnas Perempuan]. (2018). Tergerusnya ruang aman perempuan dalam pusaran politik populisme. Catatan tahunan 
kekerasan terhadap perempuan 2018. Komisi Nasional Anti Kekerasan Terhadap Perempuan.

Child Welfare Information Gateaway. (2018). The risk and prevention of maltreatment of children with disabilities. U.S. Department of Health and Human Services, Children's Bureau.

Davies, E. A., \& Jones, A. C. (2013). Risk factors in child sexual abuse. Journal of Forensic and Legal Medicine, 20(3), 146-150. https://doi.org/10.1016/j.jflm.2012.06.005

Embry, R. A. (2001). Examination of risk factors for maltreatment of deaf children: Findings from a national survey. Dalam 7th International Family Violence Research Conference, Portsmouth, $\mathrm{NH}$.

Finkelhor, D. (2009). The prevention of childhood sexual abuse. Journal of the Future Children, 19(2), 169-194. http://doi.org/10.1353/foc.0.0035

Gray, K., Rand, D. G., Ert, E., Lewis, K., Hershman, S., \& Norton, M. I. (2014). The emergence of "us and them" in 80 lines of code: Modeling group genesis in homogeneous $\begin{array}{llll}\text { populations. } & \text { Psychological } & \text { Science, } & \text { 25(4), }\end{array}$ https://doi.org/10.1177/0956797614521816

Hornor, G. (2010). Child sexual abuse: Consequences and implications. Journal of Pediatric Health Care, 24(6), 358-364. https://doi.org/10.1016/j.pedhc.2009.07.003

Johnson, C. F. (2004). Child sexual abuse. Lancet, 364(9432), 462-470. https://doi.org/10.1016/S0140-6736(04)16771-8

Kinnear, K. L. (2007). Child sexual abuse: A reference handbook (Edisi kedua). ABC-Clio.

Kellog, N. (2005). The evaluation of sexual abuse in children. Pediatrics, 116(2), 506-512. https://doi.org/10.1542/peds.2005-1336

LaBrot, Z. C., Radley, K. C., Dart, E., Moore, J. \& Cavell, H. J. (2017). A component analysis of behavioral skills training for effective instruction delivery. Journal of Family Psychotherapy, 29(2), 122-141. https://doi.org/10.1080/08975353.2017.1368813

Luft, P. (2017). What is different about deaf education? The effects of child and family factors on educational services. The Journal of Special Education, 51(1), 27-37. https://doi.org/10.1177/0022466916660546

Mardhiyah, Z. (2017). Validasi modul "LINGKARAN" untuk meningkatkan keterampilan orang tua menyampaikan prevensi kekerasan seksual anak (Tesis tidak dipublikasikan). Fakultas Psikologi, Universitas Gadjah Mada.

McLean, C. P., Morris, S. H., Conklin, P., Jayawickreme, N., \& Foa, E. B. (2014). Trauma characteristics and posttraumatic stress disorder among adolescent survivors of childhood sexual abuse. Journal of Family Violence, 29(5), 559-566. https://doi.org/10.1007/s10896-014-9613-6

Modelli, M. E. S., Galvão, M. F., \& Pratesi, R. (2012). Child sexual abuse. Forensic Science International, 217(1-3), 1-4. https://doi.org/10.1016/j.forsciint.2011.08.006

Narcosetyo, B. D. Y. (2017). Validasi modul "ORIGAMI" pada orang tua untuk prevensi kekerasan seksual anak tunarungu (Tesis tidak dipublikasikan). Fakultas Psikologi Universitas Gadjah Mada.

Nunnally, J. C., \& Bernstein, I. H. (1994). Psychometric theory (Edisi ketiga). McGraw-Hill. 
Nyarko, K., Adentwi, K. I., Asumeng, M., \& Ahulu, L. D. (2014). Parental attitude towards sex education at the lower primary in Ghana. International Journal of Elementary School, 3(2), 21-29. https://doi.org/10.11648/j.ijeedu.20140302.11

Quittner, A. L. , Barker, D. H., Cruz, I., Snell, C., Grimley, M. E., Botteri, M., \& Investigative Team, CDaCI. (2011). Parenting stress among parents of deaf and hearing children: Associations with language delays and behavior problems. Parenting, 10(2), 136-155. https://doi.org/10.1080/15295190903212851

Richter, L., Makusha, T., Komárek, A., Daniels, J., \& Coates, T. (2015). Exploring the impact of childhood abuse on HIV social and attitudinal factors among adults with and without this history in Sub-Saharan African: Findings from NIMH Project Accept (HPTN 043). Journal of AIDS Behavior, 20(4), 737-745. https://doi.org/10.1007/s10461-015$\underline{1166-\mathrm{Z}}$

Rustika, I. M. (2012). Efikasi diri: Tinjauan teori Albert Bandura. Buletin Psikologi, 20(1-2), 1825.

Sanders, M. R., \& Woolley, M. L. (2005). The relationship between maternal self-efficacy and parenting practices: Implications for parent training. Child: Care, Health, and Development, 31(1), 65-73. https://doi.org/10.1111/j.1365-2214.2005.00487.x

Shadish, W.R., Cook, T.D., \& Campbell, D.T. (2002). Experimental and quasi experimental designed for generalized causal inference. Houghton Mifflin Company.

Shultz, K. S., Whitney, D. J., \& Zickar, M. J. (2014). Measurement theory in action: Case study and exercises. Taylor \& Francis.

Skarbek, D., Hahn, K., \& Parrish, P. (2009). Stop sexual abuse in special education: An ecological model of prevention and intervention strategies for sexual abuse in special education. Sexuality and Disability, 27(3), 155-164. https://doi.org/10.1007/s11195-0099127-y

Sullivan, P. M., \& Knutson, J. F. (2000). Maltreatment and disabilities: A population-based epidemiological study. Child Abuse \& Neglect, 24(10), 1257-1273. https://doi.org/10.1016/S0145-2134(00)00190-3

Walsh, K., \& Brandon, L. (2012). Their children's first educators: Parent's views about child sexual abuse prevention education. Journal of Child and Family Studies, 21(5), 734-746. https://doi.org/10.1007/s10826-011-9526-4

Widhiarso, W. (2011). Aplikasi ANAVA campuran untuk desain eksperimen pre-post test design. Fakultas Psikologi, Universitas Gadjah Mada.

Wurtele, S. K. (2008). Behavioral approaches to educating young children and their parents about child sexual abuse prevention. Journal of Behavior Analysis of Offender and Victim Treatment and Prevention, 1(1), 52-64. http://dx.doi.org/10.1037/h0100434

Wurtele, S. K., \& Kenny, M. C. (2010). Partnering with parents to prevent childhood sexual abuse. Child Abuse Review, 19(2), 130-152. https://doi.org/10.1002/car.1112

Wurtele, S. K., Moreno, T., \& Kenny, M. C. (2008). Evaluation of a sexual abuse prevention workshop for parents of young children. Journal of Child \& Adolescent Trauma, 1(4), 331340. https://doi.org/10.1080/19361520802505768 
Xie, Q. W., Qiao, D. P., \& Wang, X. L. (2015). Parent-involved of child sexual abuse: A qualitative explorations of parents' perceptions and practices in Beijing. Journal of Child Family Study, 25(3), 999-1010. https://doi.org/10.1007/s10826-015-0277-5 